prof. dra hab. Jana Dzięgielewskiego, oscylowały przede wszystkim wokół zagadnień kształcenia w szkołach wybranych klasztorów czy zakonów.

Warto podkreślić, że konferencja zgromadziła wielu specjalistów z zakresu historii szkolnictwa kościelnego i charakteryzowała się wysokim, akademickim poziomem. Prelegenci przyjęci zostali ze szczególnymi honorami przez organizatorów.

Michat Nowicki

\title{
„Szkoła polska od średniowiecza do XX wieku. Między tradycją a innowacją" - Seminarium w Zakładzie Historii Oświaty i Wychowania na Wydziale Pedagogicznym Uniwersytetu Warszawskiego, 14 października 2010 r.
}

14 października 2010 r. odbyło się spotkanie - seminarium, podsumowujące pracę nad opublikowaną w roku 2010 przez Zakład Historii Oświaty i Wychowania na Wydziale Pedagogicznym Uniwersytetu Warszawskiego książką „Szkoła polska od średniowiecza do XX wieku. Między tradycją a innowacją" (pierwotnie planowana była dwudniowa konferencja we wrześniu, ale dokładnie w przewidzianym przez Zakład terminie, został zwołany Zjazd Polskiego Towarzystwa Pedagogicznego w Toruniu). Publikacja zawiera 29 tekstów autorskich w ośmiu działach, w układzie chronologicznym i terytorialno - politycznym. Część pierwsza obejmuje 4 rozprawy od średniowiecza do końca XVIII wieku; następne trzy części grupują kolejno rozprawy odnoszące się do edukacji szkolnej „czasu zaborów”, kolejna część - „ponad zaborami” grupuje teksty, wykraczające poza cezurę chronologiczną i geograficzną zaborów. Najobszerniej prezentuje się część zatytułowana „W Drugiej Rzeczypospolitej” obejmująca 7 rozpraw, najskromniej dział „W Polsce Ludowej” - tylko dwa teksty. Całość zamyka esej o potrzebie wglądania w przeszłość edukacyjną przy dzisiejszym uprawianiu pedagogiki i przenoszeniu jej koncepcji do praktyki.

W seminarium uczestniczyło 47 osób reprezentujących wiele środowisk historyków wychowania, historyków, pedagogów, a wśród nich większość Autorek i Autorów, którzy w pierwszej części spotkania zaprezentowali idee przewodnie swoich rozpraw. Tej części seminarium przewodniczył Profesor Karol Poznański. Część drugą spotkania (przewodniczyła Irena Szybiak, prof. UW) wypełniła dyskusja, w toku której uczestnicy seminarium zaprezentowali bogaty zbiór pytań i problemów do rozwiązania.

Debatę rozpoczął dr Adam Fijałkowski (członek zespołu redakcyjnego), podkreślając, że ideą publikacji było skupienie uwagi przede wszystkim na rzeczywistości szkolnej, w mniejszym stopniu na ideologii wychowawczej a także zgromadzenie obrazów tej rzeczywistości, tak by można z nich wyprowadzić sądy ogólne. 
Profesor Lech Mokrzecki w swoich wystąpieniach zwrócił uwagę na potrzebę uwzględnienia w badaniach zagadnień wielonarodowości i zróżnicowania wyznaniowego i religijnego w Rzeczpospolitej - co musiało wpływać na kształt elit społecznych w dawnej Polsce. Potrzebne są badania porównawcze działalności szkół, funkcjonujących w różnych środowiskach religijnych i wyznaniowych. Ponadto, odnosząc się do wypowiedzi Kaliny Bartnickiej (zob. niżej) zauważył, ze większość tekstów - opublikowanych w książce, która wywołała tę dyskusję - dotyczy historii edukacji od przełomu XVII i XVIII wieku do XX wieku. Zdecydowanie w mniejszym wymiarze prezentowane są wyniki badań nad szkołą i edukacją w okresie staropolskim, a zakres pytań jest obszerny i obejmuje konfesyjność, wielostanowość, stosunek nauczycieli do wydarzeń politycznych, funkcjonowanie szkoły w środowisku, zainteresowanie szkołą ze strony władz miejskich. Wiele z tych pytań można odnieść do kolejnych epok.

Dr Tomasz Maliszewski postulował podejmowanie badań porównawczych. Zwrócił uwagę na niedostatek badań recepcji w środowisku polskich pedagogów i nauczycieli w XIX wieku zachodnioeuropejskiej myśli pedagogicznej.

Dr Krzysztof Ratajczak sygnalizował niedostatek badań nad dziejami starożytnymi oraz dysproporcję między liczbą badaczy okresu staropolskiego a badaczami czasów nowych. Brakuje analiz finansowania szkolnictwa, programów stypendialnych a także wspierania żebraków - scholarzy. Zwrócił także uwagę na potrzebę zintensyfikowania relacji między historią wychowania a historią „bez przymiotnikową”, w obrębie której bada się także dzieje szkolnictwa.

Profesor Grażyna Dryżałowska - dziekan Wydziału Pedagogicznego UW - zauważyła obecność w publikacji problematyki edukacji niepełnosprawnych. Polem badań, istotnym dla pedagogiki specjalnej, jest zagadnienie uwarunkowań prawnych funkcjonowania szkół specjalnych w poszczególnych zaborach.

Dr Elżbieta Magiera sformułowała kilka konkretnych obszarów badań pod kątem trwania i zmienności: ideał wychowawczy, metody i formy wychowania, obrzędowość szkolna, imprezy szkolne itp. Zwróciła uwagę na potrzebę sięgania do źródeł, wytwarzanych nie tylko przez szkołę i inne instytucje wychowania, ale także do różnych rodzajów prasy - wskazała na wartość źródłową np. prasy spółdzielczej.

Obszerną listę pytań i problemów badań, jakie wyłaniają się z publikacji, dotyczących zagadnień: szkoła jako instytucja i szkoła jako element społeczności, sformułowała Profesor Kalina Bartnicka. Wskazała na potrzebę badania procesów zmian programów i metod nauczania, obszarów laicyzacji i konfesyjności programów oraz indoktrynacji uczniów w toku edukacji szkolnej oraz relacji: nauczyciele a wydarzenia polityczne. W badaniu funkcjonowania szkoły w środowisku, należałoby - Jej zdaniem - pytać o to, czego społeczeństwo oczekiwało i oczekuje od procesu edukacji szkolnej; o zagadnienie utartych znaczeń: szkoła prywatna dawniej - szkoła prywatna dziś; o tradycję i trwanie w połączeniu z pytaniem, dlaczego tylko niektóre szkoły mają wielowiekową historię oraz o regionalne czynniki rozwoju szkół. Jednym ze szczegółowych zagadnień powinna być rola i miejsce języka polskiego w szkole pod zaborami, a także zjawisko akceptacji przez polską społeczność szkoły zawodowej, nawet jeśli kształcenie odbywało się w języku zaborcy. Badaniu powinny zostać poddane także takie zjawiska, jak stopień unowocześniania 
zaborczych systemów szkolnych; rola szkół dokształcających, które były swoista formą wydłużania obowiązku szkolnego; koedukacja i jej związek z udostępnianiem dziewczętom szkół publicznych.

W zakresie studiów nad programami nauczania szkolnego K. Bartnicka wskazała na potrzebę analiz „książek długiego trwania” - Iliady, Odysei, Biblii - pod kątem ich wartości kształcącej i wychowawczej. Zauważyła także potrzebę badań pierwszych doświadczeń państwa w administrowaniu szkołami, zarówno przez Komisję Edukacji Narodowej jak i nad powstawaniem kadry urzędniczej w tym zakresie, w kontekście oporu uniwersytetu wileńskiego - po rozbiorach - przed oddaniem tego nadzoru urzędnikom. W nawiązaniu do ostatniego tekstu, dotyczącego relacji między pedagogiką a historią wychowania, jako istotne pole refleksji wskazała zagadnienie roli historii wychowania w kształceniu pedagogicznym - wprowadzenie doświadczenia historycznego do ogólnej i szczegółowej wiedzy z zakresu pedagogiki zdobywanej przez studentów.

Dyskusja ujawniła zatem, że Autorzy zamieszczonych w książce tekstów otwierają kolejne perspektywy badawcze. Przykładem są rozprawy ukazujące np. szkołę niemiecką, nie tylko pod kątem jej celów germanizacyjnych, ale także jako instytucję kształcącą, otwierającą przed młodzieżą perspektywy przygotowania do pracy zawodowej i funkcjonowania $\mathrm{w}$ społeczeństwie, a $\mathrm{z}$ drugiej strony - nieformalny program samoobrony rodzin polskich przed wynarodowieniem.

Irena Szybiak 